\title{
Perancangan Sistem Informasi Manajeman Inventory Dengan Menggunakan Ms. Visual Foxpro 6.0 Pada Kantor Dinas Badan Pusat Statistik (Bps) Lampung Selatan
}

\author{
Arnes Yuli Vandika \\ Program Studi Teknik Informatika \\ Fakultas Ilmu Komputer \\ Universitas Bandar Lampung \\ Jln. Z.A. Pagar Alam No.26 Labuhan Ratu Bandar Lampung 35142 \\ Telp. (0721) 701463, (0721) 701979 Fax. (0721) 701467 Web. www.ubl.ac.id
}

\begin{abstract}
Abstrak
Dengan kemajuan ilmu dan teknologi yang kini berkembang pesat, khususnya dalam pengolahan data barang inventaris banyak orang yang menggunakan sistem komputerisasi untuk mencapai hasil yang lebih sempurna, mempercepat dan mempermudah pekerjaan. Kantor Dinas Badan Pusat Statistik (BPS) Lampung Selatan diharapkan meninggalkan cara manual dalam mencatat data-data inventaris barang, karena akan mengurangi efektifitas kerja sehingga hasilnya kurang dirasakan optimal.

Skripsi ini akan menggambarkan serta menjelaskan perancangan sistem informasi manajemen inventory pada Kantor Dinas Badan Pusat Statistik (BPS) Lampung Selatan. Dalam merancang sistem, peneliti menggunakan perancangan program yang dijelaskan pada bagian keempat dari Skripsi ini.
\end{abstract}

Kata Kunci : Perancangan, Sistem, Sistem Informasi Manajemen Inventory

\section{PENDAHULUAN}

Seiring dengan berkembangnya teknologi komputer dewasa ini baik berupa mesin-mesin otomatis maupun komputerisasi, baik berupa perangkat keras (Hardware) maupun perangkat lunak (Software), sangat tidak mengherankan apabila instansi-instansi pemerintah maupun non pemerintahan dan lembaga-lembaga pendidikan angat memerlukan peranan komputer, terutama dalam pengolahan data yang masih banyak diantaranya menggunakan cara-cara manual, sehingga efisiensi dan efektivitas pekerjaan yang dibutuhkan tidak sesuai dengan yang diharapkan. Di dunia kerja contohnya, setiap pegawai diharuskan untuk mempergunakan waktu seefisien mungkin agar dapat memperoleh hasil yang maksimal. Mengingat begitu banyak tugas yang harus dikerjakan, maka Kantor Dinas Badan Pusar Statistik (BPS) Lampung Selatan harus menggunakan teknologi komputer sesuai dengan perkembangan saat ini dalam mengerjakan tugastugas tersebut. Pemakaian komputer adalah sebagai alat Bantu yang dirasakan sangat penting bagi perusahaan-perusahaan besar dan juga banyak digunakan oleh perusahaan kecil, instansi pemerintah, dan lembaga pendidikan yang membutuhkan kinerja yang cepat dari komputer.

Pengolahan data pada Kantor Dinas Badan Pusat Statistik (BPS) Lampung Selatan khususnya pada bagian inventaris barang membutuhkan ketelitian serta keakuratan dalam pencatatan data barang inventaris. Sedangkan pengolahan data secara semi komputerisasi yang sedang berjalan saat ini sudah semakin tidak dapat memenuhi kebutuhan untuk masa-masa sekarang karena efisiensi dan efektivitas yang rendah. Untuk itu kehadiran komputer dan berbagai program aplikasi saat ini merupakan solusi yang dapat membantu dalam pengolahan data dimana kesalahan dan keterlambatan pembuatan laporan yang sangat dibutuhkan akan dapat ditekan serendah dan sekecil mungkin.

Menanggapi permasalahan itulah, maka peneliti ingin membantu merancang sebuah sistem informasi manajemen inventory pada Kantor Dinas 
Badan Pusat Statistik (BPS) Lampung Selatan dengan menggunakan bahasa pemrograman Visual FoxPro 6.0.

\subsection{Permasalahan}

Berdasarkan identifikasi masalah tersebut, maka peneliti akan membuat sistem intuk mengatasi kendala-kendala tersebut, yaitu " Perancangan Sistem Informasi Manajemen Inventory pada Kantor Dinas Badan Pusat Statistik (BPS) Lampung Selatan dengan menggunakan Visual FoxPro 6.0 Pada Bagian Inventarisasi Barang supaya dapat dilakukan secara cepat, tepat dan akurat sehingga dapat juga diperoleh informasi data barang inventaris yang maksimal sesuai yang dibutuhkan".

\subsection{Batasan Masalah}

Perancangan program ini hanya sebatas pada perancangan sistem informasi manajemen inventory pada bagian Inventarisasi Barang pada Kantor Dinas Badan Pusat Statistik (BPS) Lampung Selatan, mulai dari pengadaan barang, pemberian nama atau label pada barang sampai barang tersebut diinventariskan, dan lainnya yang berhubungan dengan inventaris barang. Untuk itu peneliti mencoba menyelesaikan permasalahan data yang masih dilakukan secara manual atau semi komputerisasi, dibuat dengan menggunakan program Visual FoxPro 6.0 supaya dapat menyajikan informasi dalam waktu yang relative cepat dan tepat.

\subsection{Tujuan}

1. Sebagai salah satu syarat dalam menyelesaikan Program Sarjana ( S1) Fakultas Ilmu Komputer Program Studi Teknik Informatika Universitas Bandar Lampung.

2. Sebagai bahan skripsi yang dibuat peneliti sebagai syarat kelulusan.

3. Peneliti ingin memperkenalkan suatu sistem informasi manajemen inventory dengan menggunakan bahasa pemrograman Visual FoxPro 6.0 pada Kantor Dinas Badan Pusat Statistik (BPS) Lampung Selatan.

\subsection{Bahasa Pemrograman}

Di dalam pengkodean adalah menterjemahkan desain ke dalam bahasa pemrograman actual, sebagian besar kesulitan telah harus terpecahkan pada tahap sebelumnya, sehingga pemrogram bebas untuk mencurahkan perhatian penuh untuk pembuatan program. Bahasa pemrograman merupakan kendaraan yang digunakan untuk berkomunikasi antara manusia dengan mesin komputer. Fungsi dari bahasa pemrograman adalah sebagai media untuk membuat program dan memahami serta sebagai alat komunikasi antara pemrogram dan komputer. Beberapa kriteria yang digunakan untuk mengevaluasi pemilihan bahasa pemrograman adalah :

a. Bidang aplikasi yang sedang dikerjakan,

b. Kekomplekkan algoritma dan perhitungan,

c. Lingkungan dimana perangkat lunak akan diterapkan,

d. Pengetahuan staff akan bahasa pemrograman,

e. Ketersediaan kompilasi yang baik.

\subsection{Mengenal Pemrograman Visual FoxPro 6.0}

Visual FoxPro adalah salah satu bahasa pemrograman computer. Bahasa pemrograman adalah perintah-perintah atau instruksi-instruksi yang dimengerti oleh computer untuk tugas-tugas tertentu. Visual FoxPro merupakan salah satu Development Tool yaitu alat bantu untuk membuat berbagai macam program aplikasi, khususnya yang menggunakan sistem operasi windows. Visual FoxPro merupakan salah satu bahasa pemrograman komputer yang mendukung objek (Object Oriented Programming $=$ OOP $)$. (Krisna D.Octoviana, 2003:1)

OOP yaitu bahasa pemrograman generasi ke-IV yang berorientasi objek yang merupakan salah satu bahasa yang digunakan untuk membangun aplikasi, yang mempunyai kelebihan dalam pengolahan data base dan mempunyai media penyimpanan datanya yang cukup besar.

\subsubsection{Manfaat Visual FoxPro 6.0}

Adapun beberapa Manfaat dari Visual FoxPro 6.0 yaitu :

1. Untuk membuat aplikasi berbasis windows.

2. Memberikan kemudahan dalam membuat program aplikasi.

3. Mempermudah pemrogram untuk membuat objek-objek yang dibutuhkan dalam membuat sebuah program aplikasi.

\subsubsection{Keistimewaan Visual FoxPro 6.0}


Adapun beberapa keistimewaan dari Visual FoxPro 6.0 yaitu :

1. Memiliki compiler yang dapat menghasilkan file executable yang lebih cepat dan lebih efisien dari sebelumnya.

2. Memiliki beberapa tambahan sarana Wizard yang baru. Wizard adalah sarana yang mempermudah didalam pembuatan aplikasi dengan mengotomatisasi tugas-tugas tertentu.

3. Memiliki beberapa versi atau edisi yang disesuaikan dengan kebutuhan pemakainya.

4. Sarana akses data yang lebih cepat dan handal untuk membuat aplikasi database yang berkemampuan tinggi.

5. Memiliki definisi debugging dan menghasilkan program akhir berakhiran EXE yang bersifat executable, atau dapat langsung dijalankan. Jika program tidak jalan FoxPro langsung memberikan definisi debugging error.

\subsubsection{Peralatan yang diperlukan untuk aplikasi FoxPro 6.0}

1. Hardware

Yaitu perangkat keras yang dibutuhkan guna mendukung kelancaran program FoxPro 6.0 antara lain sebagai berikut :

- Personal computer Pentium 223 MMX

- Monitor SVGA

- Card VGA 1 MB

- Minimal 32 MB RAM

- Hard Disk minimal 4,3 GB

- CD Room drive digunakan apabila FoxPro 6.0 belum diinstal

2. Software

Syarat perangkat lunak yang harus dipenuhi adalah sebagai berikut :

- Sistem Operasi Windows 95, 98, 2000 atau Windows XP

- Bahasa Pemrograman FoxPro 6.0

\subsubsection{Integrated Development Environment (IDE)}

Tampilan bidang kerja pada pemrograman Visual FoxPro disebut dengan Integrated Development Environment. IDE adalah tampilan FoxPro yang Diciptakan untuk memudahkan user dalam membuat sebuah aplikasi dengan FoxPro. Melalui IDE inilah pemrogram secara visual merancang tampilan untuk pemakai (antar muka pemakai) dan menuliskan kode program. IDE secara garis besar terdiri dari bagian-bagian utama, yaitu :

1. Baris Menu

Basis Menu adalah sebuah bidang horizontal yang memanjang di bagian atas IDE dan berguna untuk menampung perintah-perintah sejenis (menu) yang telah disediakan.

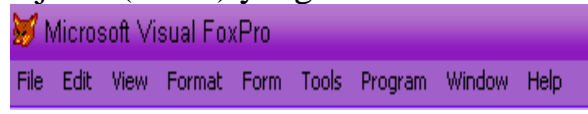

Gambar 2.1 Baris Menu

2. Control Menu

Control Menu merupakan salah satu bagian untuk memanipulasi jendela Visual FoxPro. (Abdul Razaq, 2004:11) Control Menu ini berada di pijok kiri atas dari jendela Visual FoxPro. Apabila di klik (pilih), maka akan terlihat beberapa pilihan yaitu :

a. Restore : digunakan untuk mengembalikan ukuran jendela kedalam ukuran sebelumnya.

b. Move: digunakan untuk memindahkan jendela sesuai dengan keinginan.

c. Size : digunakan untuk merubah ukuran jendela.

d. Minimize : digunakan untuk mengecilkan ukuran jendela, sehingga aplikasi akan terparkir.

e. Maximize : digunakan untuk memperbesar ukuran jendela dalam satu layer penuh.

f. Close: digunakan untuk mengakhiri atau menutup jendela.

4. Toolbar

Toolbar adalah bagian dari Visual FoxPro 6.0 yang menyediakan tombol-tombol speed yaitu tombol yang fungsinya sama dengan perintah yang ada pada menu. Tombol ini disediakan dengan

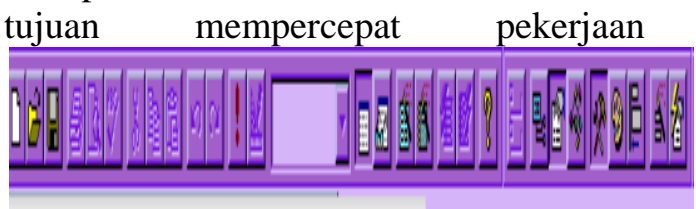

Gambar 2.2 Toolbar kita.

\section{Jendela Form}


Jendela Form (Form Window) merupakan jendela utama dalam bekerja dengan Visual FoxPro 6.0. Karena pada Form inilah dapat ditempatkan beberapa objek, misalnya label atau teks, gambar, tombol-tombol perintah dan sebagainya. Semua objek yang ditempatkan pada form akan dijalankan atau ditampilkan pada layer window. Pada Form ini sebagai dasar dari aplikasi yang dibuat. (Abdul Razaq, 2004:14)

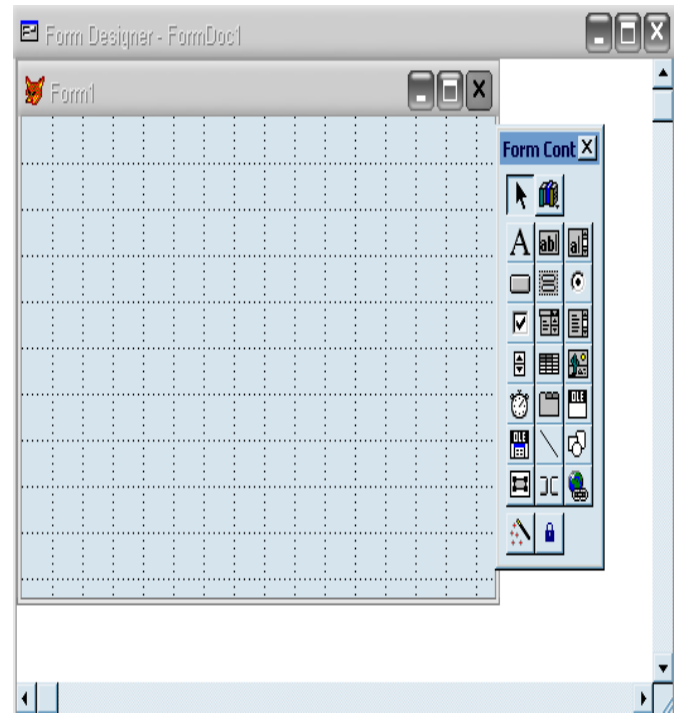

Gambar 2.3 Jendela Form pada Visual Foxpro 6.0

\section{Tampilan Microsoft Foxpro 6.0}

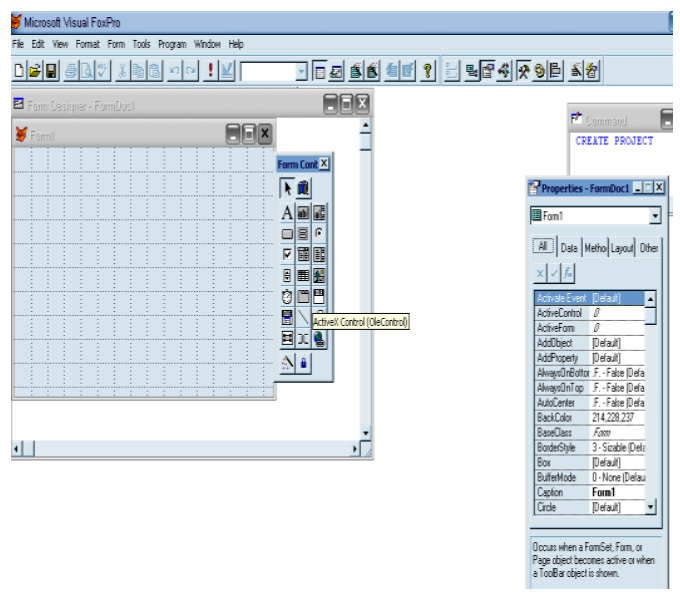

Gambar 2.4 Tampilan Microsoft Visual Foxpro 6.0

Tampilan diatas merupakan tampilan Microsoft Visual Foxpro 6.0 secara umum, yaitu terdiri dari, Control Menu, Menu Bar, Toolbox, Project Explorer, dan Properties Window, dan Form Layout.

\section{Project Explorer}

Project explorer merupakan salah satu jendela pada Visual FoxPro yang berisi semua file dalam aplikasi yang telah dibuat. Karena aplikasi yang telah dibuat merupakan suatu project yang akan berisi beberapa file, misalnya form, reports, labels, dan sebagainya. (Abdul Razaq, 2004:16)

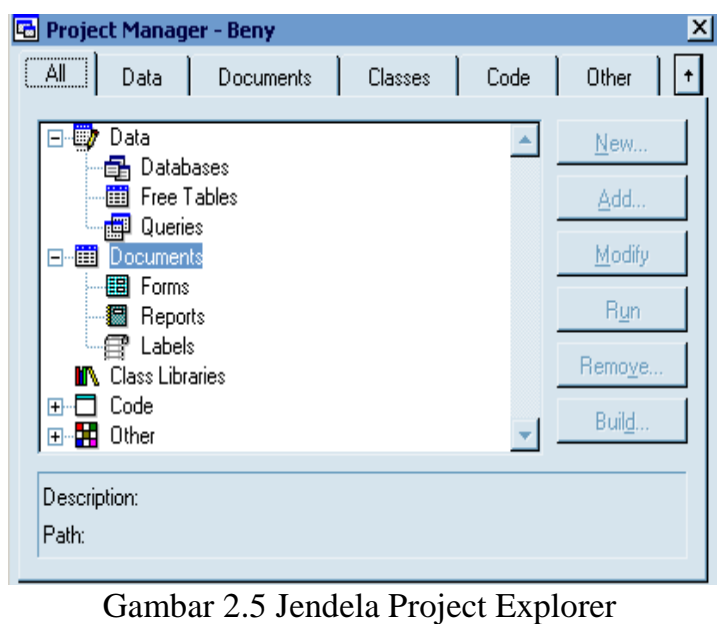

\section{Jendela Properties}

Properties berisi semua informasi tentang sifat dari sebuah obyek. Menentukan properties ini sesuai dengan kebutuhan dari obyek. Setiap obyek dapat berbeda sifatnya sesuai dengan kebutuhan dari obyek tersebut. Properties tersebut antara lain, nama obyek, warna, ukuran, posisi dan lain sebagainya. (Abdul Razaq, 2004:16-17) 


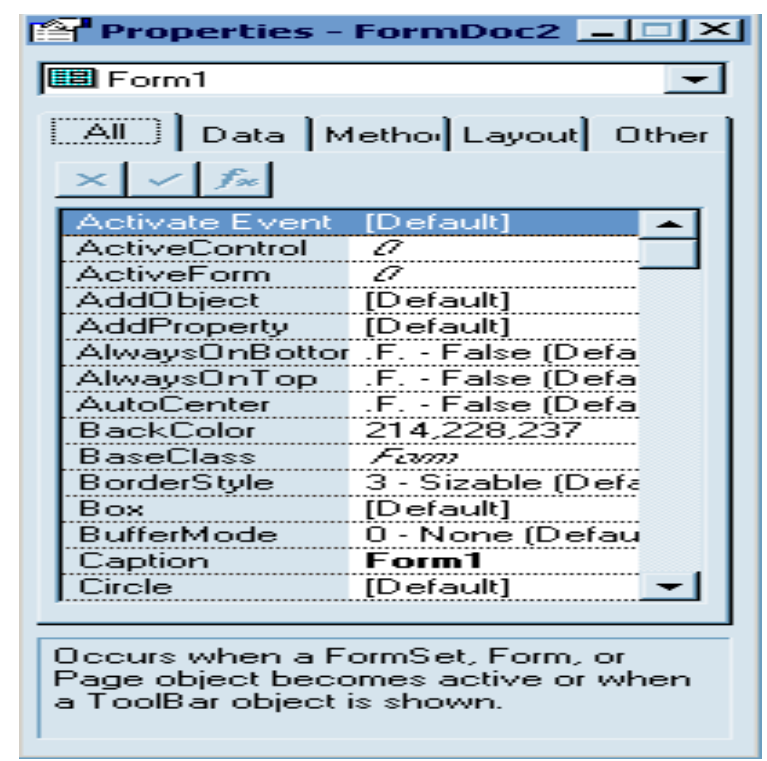

Gambar 2.6 Jendela Properties

Kegunaan dari masing-masing komponen pada Visual FoxPro 6.0 adalah sebagai berikut :

1. Tex Box digunakan untuk mengentrikan teks satu baris.

2. Edit Box digunakan untuk mengisi data lebih dari satu baris.

3. Label digunakan untuk membuat text seperti judul dan sebagainya.

4. Option Group digunakan untuk membuat kontrol pilihan, dimana kontrol ini terpilih apabila diklik pada kotak tersebut.

5. Check Box digunakan untuk membuat kontrol pilihan dengan mengisi tanda centang $(\sqrt{ })$, dimana kontrol ini terpilih apabila diklik pada kotak tersebut.

6. Combo Box digunakan untuk membuat kontrol kombinasi antara text box dan list box.

7. List Box digunakan untuk menampilkan daftar pilihan yang bias dipilih.

8. Select digunakan untuk memilih komponen.

9. View Class digunakan untuk menampilkan class buatan.

10. Command Button digunakan untuk membuat tombol.

11. Command Group digunakan untuk membuat tombol lebih dari satu.

12. Spinner digunakan untuk mengisi data berupa angka.
13. Grid digunakan untuk menampilkan recordrecord pada table.

14. Image digunakan untuk menampilkan gambar dan icon.

15. Timer digunakan untuk membuat kontrol waktu.

16. Page Frame digunakan untuk membuat tampilan dengan halaman yang banyak.

17. Horizontal Scoll Bar digunakan untuk membuat penggulung tampilan secara horizontal.

18. Line digunakan untuk membuat garis.

19. Shape digunakan untuk membuat kotak persegi panjang maupun lingkaran.

20. Container digunakan untuk membuat bingkai.

21. ActiveX Control (OLE Control) digunakan untuk menghubungkan form dengan software lain (Misalnya dengan Microsoft Excel).

22. ActiveX Bound Control (OLE Bound Control) digunakan untuk mengambil komponen kontrolain.

\subsection{Metode Penelitian}

Metode penelitian yang digunakan dalam penelitian ini ditinjau dari sudut pandang yang berhubungan dengan obyek yang diteliti adalah deskriptif research. Karena penelitian ini dilakukan dengan cara membuat deskripsi permasalahan yang telah diidentifikasi dan peneliti berusaha menjelaskan obyek yang diteliti dengan sudut pandang peneliti (meskipun bersifat subyektif).

Metode Deskriptif adalah suatu metode dalam meneliti status sekelompok manusia, suatu objek, suatu set kondisi, suatu sistem pemikiran ataupun suatu kelas peristiwa pada masa sekarang.

Kemudian dilakukan sebuah study kasus ( case study) yaitu penelitian tentang status subjek penelitian yang berkenaan dengan suatu fase spesifik atau khas dari keseluruhan personalitas. Tujuan dari studi kasus adalah untuk memberikan gambaran secara detail tentang latar belakang, sifat - sifat serta karakter yang khas dari kasus kemudian sifat khas tersebut dijadikan suatu hal yang bersifat umum. ( Moh. Nazir,Ph.D, 1988:66

\subsection{Teknik Pengumpulan Data 3.2.1 Kepustakaan (Library)}

Merupakan teknik pengumpulan data yang dilakukan dengan cara mempelajari sumber-sumber 
tertulis, seperti buku-buku, dan bahan-bahan tertulis lainnya yang berhubungan dengan pengetahuan teoritis mengenai masalah yang diteliti, dibaca, dicatat, dipelajari serta diresume untuk kemudian dijadikan data.

\subsubsection{Observasi (Pengamatan Langsung)}

Merupakan metode yang dilakukan dengan cara mengadakan pengamatan langsung pada obyek penelitian guna memperoleh gambaran yang lebih jelas mengenai sistem pengolahan data Barang Inventaris pada Kantor Dinas Badan Pusat Statistik (BPS) Lampung Selatan.

\subsubsection{Interview (Wawancara)}

Merupakan metode pengumpulan data melalui wawancara secara langsung terhadap orangorang yang berhubungan langsung dengan penelitian peneliti hingga memudahkan untuk mengumpulkan data.

\subsubsection{Dokumentasi}

Merupakan metode yang dilakukan dengan cara pencatatan terhadap data-data Intern yang dibutuhkan oleh peneliti yang sesuai dengan sistem yang akan dianalisa.

\subsection{Metodologi Analisis}

Metodologi analisis yang dipergunakan oleh peneliti dalam membantu menganalisa sistem pada Kantor Dinas Badan Pusat Statistik (BPS) Lampung Selatan mengenai Perancangan Sistem Informasi Manajemen Inventory.

\subsubsection{Functional Decomposition Methodelogies}

Metodologi ini menekankan pada pemecahan masalah dari sitem ke sub-sub sistem yang lebih kecil sehingga akan lebih mudah untuk dipahami.

\subsubsection{Data Flow Oriented Methodologies}

Menurut A.Ziyas Aktas metodologi ini berdasarkan pada pemecahan masalah dari tipe elemen data dan alur kegiatan data tersebut di dalam system Dalam skripsi ini, peneliti menggunakan beberapa Functional Decomposition Methodologies, yaitu :

\section{DFD (Data Flow Diagram)}

Diagram arus data (data flow diagram) atau DFD, adalah suatu gambaran grafis dari suatu sistem yang menggunakan sejumlah bentuk-bentuk simbol untuk menggambarkan bagaimana data mengalir melalui suatu proses yang saling berkaitan.

(Raymond McLeod Jr, 1998 : 316)

Dalam Diagram Aliran Data ada beberapa tingkatan, yaitu :

a. Context Diagram atau Diagram Level 0,

b. Diagram Zero atau Diagram Level 1, dan

c. Diagram Rinci atau Diagram Level 2.

2. ERD (Entity Relationship Diagram)

ERD adalah model konseptual yang mendeskripsikan hubungan antar penyimpanan (dalam DFD). Karena itu ERD berbeda dengan DFD (DFD memodelkan fungsi sistem). ERD digunakan untuk memodelkan struktur data dan hubungan antar data, karena hal ini relatif kompleks.Dengan ERD kita dapat menguji model dengan mengabaikan proses yang harus dilakukan.

3. Kamus Data (Data Dictionary)

Kamus data adalah katalog fakta tentang data dan kebutuhan-kebutuhan informasi dari suatu sistem informasi. Dengan menggunakan kamus data analisis sistem dapat mendefinisikan data yang mengalir di sistem dengan lengkap. (Jogiyanto. HM, 1999 :725)

4. Flow Of Document ( Bagan Alir Dokumen )

Bagan alir dokumen merupakan bagan alir yang menunjukkan arus dari laporan dan formulir termasuk tembusan-tembusannya. Bagan alir dokumen ini menggunakan simbol-simbol yang sama dengan yang digunakan di dalam bagan alir sistem. (Jogiyanto. HM, 1999 : 800 )

\subsection{Kelemahan dan Kelebihan Sistem yang dipakai}

\subsubsection{Kelemahan Sistem yang dipakai}

Karena sistem yang dipakai untuk pengolahan data Barang Inventaris pada Kantor Dinas Badan Pusat Statistik (BPS) Lampung Selatan, masih menggunakan Ms Excel, selain itu juga pencatatan 
datanya juga dilakukan secara manual, hal ini mengakibatkan adanya beberapa kelemahan yaitu :

\section{Waktu}

Dengan menggunakan Ms Excel membutuhkan waktu yang cukup lama dalam proses pencarian dan penyimpanan data barang inventaris, sehingga kurang efektif dan efisien. Hal ini mengakibatkan sering terjadinya kesalahan dalam penelitian jumlah barang inventaris. Dan memakan waktu yang cukup lama dalam membuat daftar barang inventaris. Sehingga menuntut petugas harus bekerja berulang kali .

2. Tenaga Kerja (Tenaga Manusia)

Bila daftar barang inventaris dibuat dengan program Ms Excel, maka petugas harus memindahkan data-data barang inventaris yang dilakukan secara manual dari buku agenda inventaris barang, jika ingin melakukan inventarisasi. Dengan demikian terbuktilah bahwa sistem yang digunakan akan memakan waktu dan menyita tenaga manusia sehingga kurang efektif dan efisien.

\subsubsection{Kelebihan Sistem yang dipakai}

Karena sistem menggunakan Ms Excel, maka akan lebih mudah dalam perhitungan jumlah barang yang akan diinventariskan dan lebih mudah dalam penyusunan datanya.

\subsubsection{Kelebihan dari Sistem yang akan diusulkan}

Dengan menggunakan Program Visual FoxPro 6.0, dalam merancang Sistem Informasi Manajemen Inventory pada Kantor Dinas Badan Pusat Statistik (BPS) Lampung Selatan memiliki kelebihan dibandingkan dengan sistem yang sedang digunakan seperti sekarang ini. Adapun kelebihan dari sistem yang baru adalah sebagai berikut :

1. Dengan menggunakan sistem yang baru dapat mempermudah dalam membuat laporan data barang inventaris.

2. Mempermudah dalam pengecekan berapa banyak barang yang diinventariskan.

3. Dapat menghindari terjadinya data yang sama atau data terduplikasi.

4. Pengolahan database akan lebih mudah, lebih cepat dan efisien.

\subsection{Software dan Hardware yang dibutuhkan}

\section{Single User}

Hardware :

a. Processor berkecepatan Min 450 Mhz.

b. Hard Disk Min. 10 GB.

c. RAM Min $64 \mathrm{MB}$.

d. 1 buah monitor SVGA.

e. Keyboard + Mouse.

f. Printer Laser jet.

Software :

a. Menggunakan basis Windows ME keatas.

b. Visual FoxPro 6.0.

c. Database menggunakan Ms. Visual FoxPro 6.0.

\section{Multi User}

\section{A. Server :}

Hardware :

a. Processor $1200 \mathrm{Mhz}$ (Pentium IV).

b. RAM 512 MB.

c. Hard Disk 40 GB.

d. Mouse + Keyboard.

e. LAN Card.

f. Printer Laser Jet.

g. 1 buah monitor SVGA.

Software :

a. Operating System Basis Windows 2000 Server.

b. Visual FoxPro 6.0.

c. Database Ms. Visual FoxPro 6.0.

Jaringan LAN (Lokal Area Network) :

a. Menggunakan Hub atau Bandwitch.

b. Menggunakan UTP Cable.

c. Menggunakan Topologi STAR.

B. Client :

Hardware :

a. Processor berkecepatan Min 450 Mhz.

b. Hard Disk Min 10 GB.

c. RAM Min $64 \mathrm{MG}$.

d. 2 buah Monitor SVGA.

e. Keyboard + Mouse.

f. Printer Laser Jet.

g. LAN Card.

Software : 
a. Operating System Basis Windows 2000 Server keatas.

b. Database Ms. Visual FoxPro 6.0.

c. Ms. Visual FoxPro 6.0.

\subsection{Sejarah Singkat Badan Pusat Statistik (BPS)}

Kegiatan statistik di Indonesia sudah dilaksanakan sejak masa Pemerintahan Hindia Belanda. Lembaga yang menangani kegiatan tersebut didirikan bulan Februari 1920 oleh Direktur Pertanian, Kerajinan, dan Perdagangan (Directeur van Landbouw Nijverheid en Handel) di Bogor yang bertugas mengolah dan mempublikasikan data statistik.

Pada tanggal 24 September 1924, pusat kegiatan kantor statistik ini dipindahkan ke Jakarta dengan nama Centraal Kantoor voor de Statistiek $(C K S)$ atau Kantor Pusat Statistik. Kegiatannya pada waktu itu diutamakan untuk mendukung kebijakan Pemerintah Hindia Berlanda. Produk perundang-undangan Kantor Pusat Statistik adalah Volkstelling Ordonnantie 1930 (Staatsblad 1930 Nomor 128) yang mengatur sensus penduduk dan Statistiek Ordonnantie 1934 (Staatsblad Nomor 508) tentang kegiatan perstatistikan. Pada tahun 1930 lembaga ini mengerjakan suatu kegiatan monumental, yaitu Sensus Penduduk yang pertama dilakukan di Indonesia.

Secara formal Badan Pusat Statistik (BPS) didasarkan pada Undang-undang No. 16 Tahun 1997 tentang Statistik, yang sebelumnya bernama Biro Pusat Statistik. Sebagai tindak lanjut dari pelaksanaan Undang-undang tersebut dibuat Peraturan Pemerintah No. 51 Tahun 1999 tentang penyelenggaraan Statistik, yang mengamanatkan bahwa BPS berkewajiban menyelenggarakan kegiatan statistik dasar.

Menurut Undang-undang No. 16 Tahun 1997 tentang Statistik, kantor BPS di daerah seperti BPS Kabupaten Lampung Selatan merupakan instansi vertical dari BPS. Secara teknis operasional BPS Kabupaten Lampung Selatan berada dibawah Bupati Lampung Selatan, sedangkan secara teknis administrative dibawah BPS.

Setiap BPS Kabupaten atau Kota dikepalai seorang Kepala BPS Kabupaten atau Kota (Pejabat Seselon IIIa). BPS Daerah bertanggung jawab melaksanakan kegiatan sensus dan survei serta bertugas membantu pemerintah daerah setempat dalam penyediaan data yang diperlukan.

Kantor Dinas Badan Pusat Statistik Lampung Selatan terletak dikomplek Kantor Pemerintahan Kabupaten Lampung Selatan yaitu di Jalan Indra Bangsawan No. 24 dengan lokasi sebelah utara Kantor Departemen Agama Kabupaten Lampung Selatan, sebelah barat dan timur Kantor Dinas Kehutanan, dan sebelah selatan Kantor Dinas Catatan Sipil dan Dinas Pendidikan.

Struktur organisasi BPS Kabipaten Lampung Selatan berdasarkan keputusan Kepala BPS No. 121 Tahun 2001 terdiri dari 5 (Lima) seksi dan 1 (Satu) Sub Bagian, yaitu Sub Bagian Tata Usaha, seksi Statistik Sosial, seksi Statistik Produksi, seksi

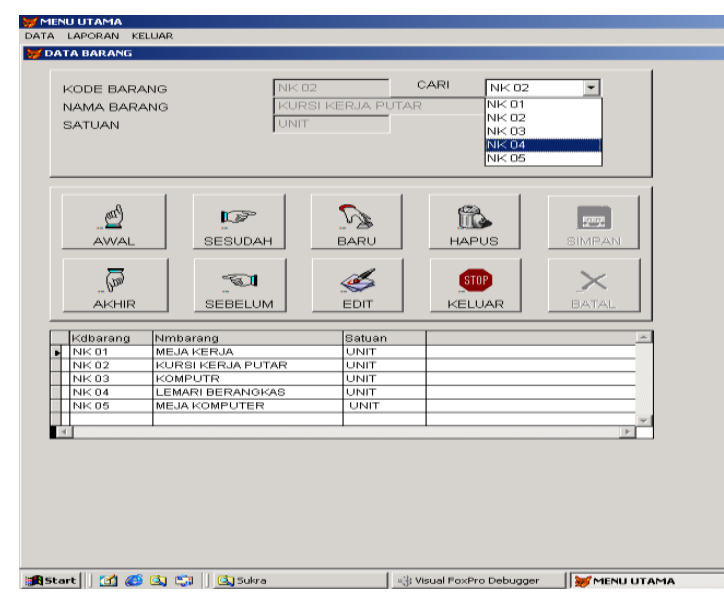

Statistik Distribusi, seksi Neraca Wilayah dan Analisis Statistik, dan seksi Statistik Integrasi Pengolahan dan Diseminasi Statistik. Sedangkan di tingkat kecamatan dapat dibentuk coordinator Statistik Kecamatan (KSK).

\subsection{TAMPILAN FORM PROGRAM JADI}

1. Tampilan Form Data Pegawai Gambar 4.1 Form Data Pegawai

2. Tampilan Form Data Barang

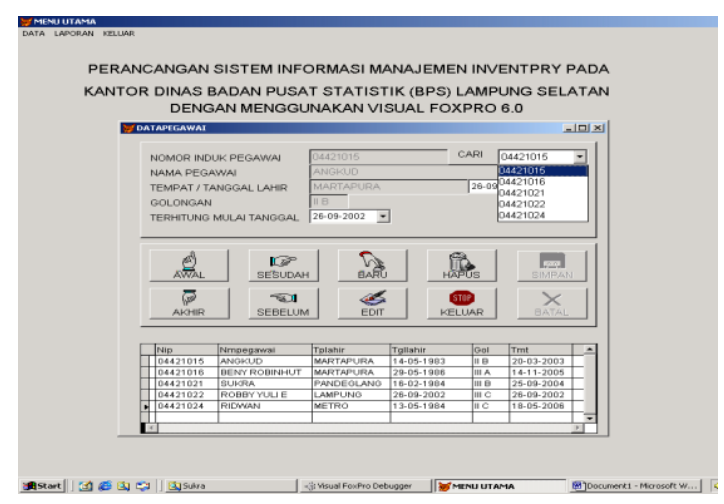


Gambar 4.13 Form Data Barang

\subsection{K mpulan dan Saran 5.1.1Kesimpulan}

Berdasarkan hasil pembahasan dari bab sebelumnya, maka peneliti dapat mengambil kesimpulan terhadap Sistem Informasi Manajemen Inventory pada Kantor Dinas Badan Pusat Statistik (BPS) Lampung Selatan, antara lain :

1. Sistem Informasi Manajemen Inventory yang sedang berjalan pada Kantor Dinas Badan Pusat Statistik (BPS) Lampung Selatan kurang efektif karena masih dilakukan secara manual atau semikomputerisasi karena hanya menggunakan Ms. Exel.

2. Karena masih menggunakan sistem manual maka sistem masih mempunyai beberapa kelemahan, antara lain:

a. Resiko kehilangan data cukup besar.

b. Kesulitan dalam pencarian data barang inventaris, sehingga sering terjadi keterlambatan dalam pembuatan laporan data inventaris.

\subsection{Saran}

Berdasarkan kesimpulan Terhadap Sistem Informasi Manajemen Inventory pada, Kantor Dinas Badan Pusat Statistik (BPS) Lampung Selatan, maka peneliti memberikan saran - saran kepada Kantor Dinas Badan Pusat Statistik (BPS) Lampung Selatan, yaitu :

1. Seiring dengan perkembangan teknologi yang terus maju, maka disarankan agar Kantor Dinas Badan Pusat Statistik (BPS) Lampung Selatan meninggalkan sistem manual dan beralih ke sistem yang terkomputerisasi.

2. Selalu mengadakan pemeriksaan jika terjadi perubahan data pada file - file yang digunakan dan dijalankan secara periodik.

\section{DAFTAR PUSTAKA}

Fathansyah,1999, Basis Data, Informatika Bandung Indra Yatini. B, Pemrograman Terstruktur, Penerbit J \& J Learning, Yogyakarta

Jogiyanto HM, 1999, Analisis dan Desain Sistem Informasi, Penerbit Andi Yogyakarta
Jogiyanto HM, 1989, Analisis dan Desain Sistem Informasi, Penerbit Andi Yogyakarta

Moh Nasir. Ph.D, 1988,Metodologi Penelitian, Penerbit Graha Indonesia

Tata Sutabri, S.Kom MM, 2003,Analisis Sistem Informasi, Penerbit Andi Yogyakarta

Tata Sutabri, S.Kom MM, 2004,Analisis Sistem Informasi, Penerbit Andi Yogyakarta 